\title{
RevistAleph
}

\section{HOMENAGEM IN MEMORIAN À JAQUELINE MORAIS}

\author{
Mairce Araujo \\ Danusa Tederiche \\ Isabele \\ Anelice Ribetto
}

\section{Jacqueline Morais: uma professora tecelã}

Em céu de azul profundo e sol ardente, sábado , 12 de outubro de 2019, dia da Padroeira do Brasil, Nossa Senhora Aparecida, a santa preta, encontrada pelos pescadores no meio do rio, Jacqueline Morais, uma professora da infância, como também gostava de se apresentar, se despediu de nós, foi morar onde moram as estrelas, como dizem os poetas...

Em nossa primeira homenagem, menos de um mês depois, na Faculdade de Formação de Professores, da Universidade do Estado do Rio de Janeiro, na 43a edição do Fórum de Alfabetização, Leitura e Escrita de São Gonçalo, FALE/SG, projeto por ela criado em parceria comigo, em 2009, não poderíamos deixar de

escolher um título mais representativo das ações e dos compromissos éticos, políticos, estéticos, investigativo-formativos, aos quais Jacque se dedicou a vida inteira, que não fosse a imagem da Professora Tecelã.

"Tecer era tudo o que fazia. Tecer era tudo o que queria fazer."

Assim como a moça tecelã de Marina Colassanti,

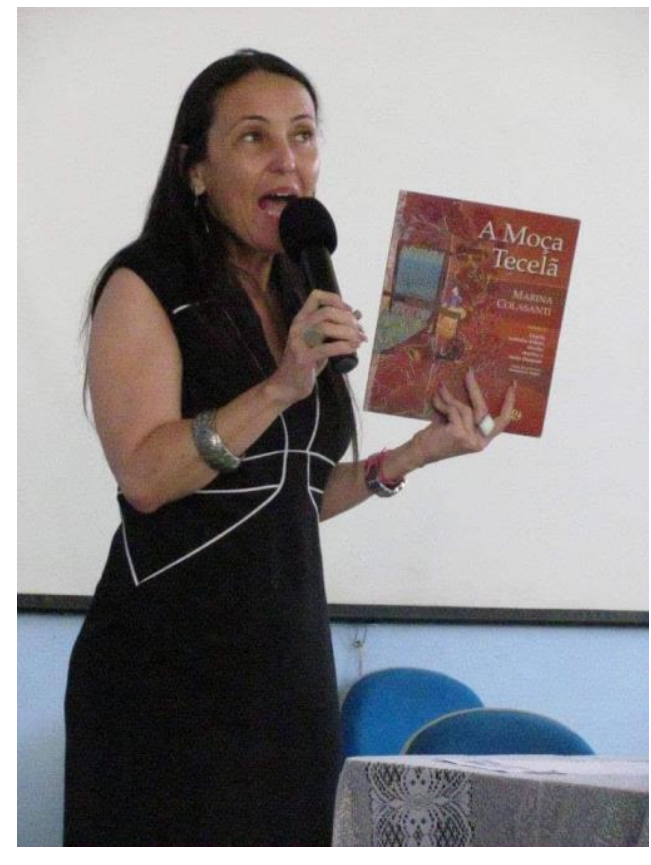
livro que leu, não sabemos quantas vezes, para quantas turmas de Alfabetização, do Curso de Pedagogia, nos Cursos de Pós-graduação Lato Sensu em Gestão da Escola Básica e no Mestrado em Educação: processos formativos e desigualdades sociais, ou nos Cursos de Formação Continuada pelo Brasil afora, ou para as turmas dos pequenos, nos anos iniciais no CapUERJ, e em tantos outros espaços, que não sabemos precisar, Jacque lia, escrevia, pesquisava, tecia.

No filme que assistia, na exposição que visitava, na peça de teatro que analisava, nos livros que lia, nas conversas que puxava com as pessoas de diferentes países pelos quais viajava, nos pequenos vídeos que fazia sobre os eventos cotidianos, tendo Walter Benjamin, como companheiro favorito, buscava selecionar "os fios teóricos" que melhor Ihe possibilitassem tecer uma compreensão sobre o cotidiano escolar, a prática 


\section{RevistAleph}

alfabetizadora, a formação docente, a América Latina, o Brasil, a política, a sociedade, enfim, a vida.

"As lembranças são como salteadores, e nos surpreendem sem aviso prévio pelo caminho", nos dizia, na página 144, do artigo Inventário - organizando os achados de uma pesquisa, publicado em 2011, no qual após defender o inventário como uma opção metodológica de organização de dados de pesquisa, termina concluindo que "talvez inventariar materiais de pesquisa seja, de certo modo, fazer um inventário de nós mesmos". (p.154)

"Inventariar o passado é um procedimento estratégico importante para os grupos que lutam pela (re)existência. Quando se quer contar uma história de certa forma é preciso mantê-la viva na memória. Os materiais recolhidos nos diferentes tempos e espaços podem ajudar a recontar a história e a fazê-lo a contrapelo. (BENJAMIN, 1996)." (MORAIS, 2011, p 151)

Recolher narrativas docentes de professoras e professores, fosse em formação inicial ou em formação continuada, na universidade ou na escola básica, alimentando o diálogo entre as duas instâncias, no Brasil ou no México, Peru, Colombia, para ajudar a contar uma história da educação a contrapelo, tendo os/as docentes como protagonistas, era um caminho para tecer redes de (re)existência aos projetos antidemocráticos experenciados recentemente na América Latina.

Em seu diário de pesquisa, um pequeno recorte da sua arte de tecer:

"Rio, inicio este que pretendo que seja meu diário de Pesquisa. Escrito à mão, de modo artesanal, como provavelmente defenderia Walter Benjamin. Estou desacostumada a escrever manualmente. O pulso dói, sem muita posição. Sinto medo de errar e não poder acrescentar uma linha entre uma frase e outra. A caneta marca o papel, tornando imóvel as letras e os pontos. Vou, portanto, ter que reaprender a lidar com a escrita não como reescrita, não como rascunho, mas como permanência. Ou aprenderei a criar outras formas de impermanência?" (Caderno de Jacqueline, 2016)

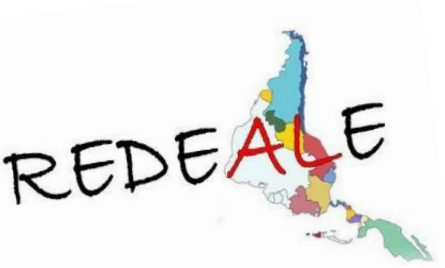

Hoje, especialmente, desafiada pelas permanências e as impermanências que a vida nos coloca a cada dia, esse pequeno texto-homenagem, não poderia deixar de resgatar igualmente uma outra experiência amorosa de parceria construída em São Gonçalo, nos últimos oito anos, nos movimentos que nos levaram ao encontro de nossos pares latinoamericanos, com o coletivo Redes Docentes que Estudam e Narram sobre Infância, Alfabetização, Leitura e Escrita (REDEALE). 


\section{RevistAleph}

Nas experiências compartilhadas com docentes no México, no Peru, na Argentina e na Colômbia nos "Encuentros Iberoamericanos de Coletivos e Redes de Maestros y Maestras que hacen investigacion e innovación desde su escuela y comunidad", com o coletivo REDEALE, fomos conhecendo "a escola no plural - que emerge

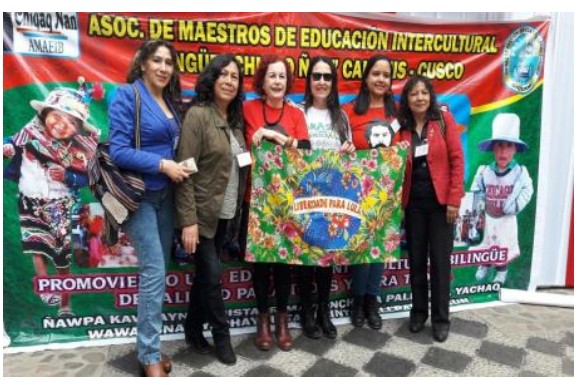
desde a cotidianidade dos saberes, dos desejos e das buscas dos que nela atuam " (BERNAL, 2010, p.2). Saberes e fazeres pedagógicos construídos/vividos em diferentes tempos e lugares, alimentados em coletivos docentes que nos ensinaram que tenemos que seguir luchando para que en América Latina las reformas neoliberales no perdure para siempre.

Como nos ensina Freire, reafirmando o compromisso político-pedagógico, com a construção de uma escola pública de qualidade e por uma sociedade latino-americana mais justa, seguimos em frente nessa luta, chamando; Jacqueline Morais, presente!

BERNAL, M.P.U. Expedição pedagógica. In: OLIVEIRA, D.A.; DUARTE, A.M.C.; VIEIRA, L.M.F. DICIONÁRIO: trabalho, profissão e condição docente. Belo Horizonte:

UFMG/Faculdade de Educação, 2010. CDROM.

MORAIS, Jacqueline de F S Morais, PRADO, Guilherme V T. Inventário - organizando os achados de uma pesquisa. In: EntreVer, Florianópolis, v. 01, n.01, p. 137-154, 2011.

Mairce Araujo

Puxando outros fios para essa homenagem: cartas para Jac

São Gonçalo, 17 de setembro de 2019

Querida Jac,

Hoje foi um dia daqueles que ia te dar orgulho, sabe!? Totalmente dedicado à pesquisa e querendo ser a melhor que posso só para ouvir você falar que Mairce iria ficar feliz comigo. E como pesquisar, escrever, narrar, investigar, relembrar minha história de vida, sem lembrar de você? Impossível! Você está na minha pesquisa, é parte dela, escrevo também sobre você. Sendo assim, hoje foi um dia que passei com você e estou feliz por isso. Estar com alguém não necessariamente é ocupar o mesmo espaço, tem tanta gente perto que está tão distante. Estar com alguém é ter esse alguém por dentro, preenchendo o coração... 


\section{RevistAleph}

Demorei um pouco para permitir sair as palavras, porque assim como o poeta, estou preferindo ser lida pelas pedras, porque as palavras me escondem sem cuidado. Se sairão todas as palavras? Jamais daria conta de findá-las, por ora, esboço apenas aquelas que precisam transbordar. Há as pessoas que concordam com a ideia que diz que o que a memória amou fica eterno. Começo a discordar, pois, por vezes, quero deseternizar algumas memórias. Farei isso, matando algumas palavras.

Retomando o nosso encontro de hoje, obrigada por me permitir a sua companhia. Foi bom estar com você, mas em breve estaremos perto novamente, é só você terminar essas férias que resolveu tirar em pleno ano letivo. Você está mudada, hein! Bom, minha querida, pode até ser em meio a uma lágrima ou outra que escolho essas palavras para registrar o que você talvez chamaria de diário, mas tenha certeza que minhas lágrimas são de alegria, gratidão pela sua vida e orgulho que estou de você por ser essa mulher forte, guerreira e que a cada dia me ensina que apesar de tudo, vale a pena seguir em frente.

Força Jac, estamos fortes aqui também, mas não se demore, pois estou com saudades até de ouvir seus diálogos acalorados com Mairce. Por ora fico por aqui com essas linhas escritas que ajudaram a transbordar meu eu em palavras.

Carinhosamente, Danusa Tederiche

Niterói, 29 de setembro de 2019

Oi Jacque,

Venho te dizer que mesmo com a distância física encontro contigo diariamente, pois acredito que a escrita é uma maneira de estar perto e sempre que leio minha dissertação lembro-me de você e do quanto estamos envolvidas com o projeto que vem sendo construído por nós.

Palavras de fé, esperança e amor nos impulsionam para a vida e é por isso que escrevo, para que você saiba que estou firme e confiante na sua recuperação. Você está sendo um grande exemplo de perseverança e paixão pela vida. Quanta coragem está demonstrando ter!

Reafirmo a importância que você tem em minha vida. Tudo que construímos ultrapassa os muros da Universidade. Confesso que estou bastante preocupada contigo, com sua saúde e que tenho rezado bastante por você, pela sua plena recuperação. Tenho aprendido que "viajar" pela vida é isso, é termos força para superar os desafios que surgem acreditando que podemos vencer nossas limitações.

Jacque me despeço preparando uma nova carta para você, caso goste dessa... rsrsrs... brincadeirinha... me despeço, com um trecho do livro "Os cinco sentidos" de Bartolomeu Campos de Queirós, trecho que escolhi hoje para iniciar a semana com meus pequenos... estamos com um projeto sobre o corpo humano e com GPALE aprendi a cantar poesia com as crianças na escola... 


\section{RevistAleph}

\section{Audição}

\section{Bartolomeu Campos de Queirós}

Com os ouvidos nós escutamos

o silêncio do mundo.

E dentro do silêncio moram todos os sons:

canto, choro, riso, lamento.

No silêncio vivem barulhos

de vento e chuva, de asa e mergulho.

É preciso o silêncio para poder escutar.

E quando uma voz invade nossos ouvidos, adivinhamos a felicidade de quem fala.

Nossos ouvidos lêem o tom das vozes.

E o ruído do vôo das abelhas

adoça o nosso dia.

Se escutamos música,

nosso corpo descansa com a melodia das notas.

Se ficamos em repouso

e prestamos sentido aos ruídos,

nosso pensamento viaja.

Visita montanha e planície,

primavera e verão.

Escutar também é um jeito de ver.

Quando nós escutamos,

imaginamos distâncias,

construímos histórias,

desvendemos novas paisagens.

Os ouvidos têm raízes pelo corpo inteiro.

Beijos, e um abraço bem apertado,

Com carinho, Isabele.

\section{Homenagem a Jacque- 5/11/2019 (FALE/FFP/UERJ)}

O QUE AINDA MERECE A PENA SER DITO?

Maestra tecelã...

Jacque tecia?

Jacque era muito ruim para tarefas manuais... mas,

Tecia textos...

Texto...

Préstamo (s. XIV) del latín textum 'tejido'... De la familia etimológica de tejer (V.).

Era uma criadora de palavras andantes, por isso criou o FALE com Mairce. 


\section{RevistAleph}

De palavras como gestos coletivos,

por isso peitou a coordenação do programa junto comigo.

De palavras infantis,

De palavras pequenas,

De palavras chatas,

De palavras de ordem,

De palavras de força políticas,

De mirada de palavra,

De unhas de palavra,

De sonhos de palavra que nunca lembrava...

Jacque do princípio ao fim, teceu palavras...

E nos primeiros e nos últimos dias juntas: ela escreveu...

Como personagem de um micro-relato de Galeano sobre Pepe Mujica, nos disse - a

cada uma de nós - aquilo que ela desejava dizer: com os olhos, com as mãos, sempre escrevendo...

Jacque Texto,

Jacque professora,

Jacque, A DE ALMA OAXAQUENA... sem dúvida a terra que deve ter acolhido ela, é uma terra cheia de mulheres com tranças, tecedoras de huipiles.

Adriana, a irmã da Jacque me deu esse huipil dela.

Um huipil é um tecido...

CUANDO UNA MUJER DE CHIAPAS SE PONE UN HUIPIL

CEREMONIAL, AUTOMÁTICAMENTE CREA ALREDEDOR DE SU

CUERPO UN ESPACIO SAGRADO, UN AMBITO DE EXCEPCIÓN

DONDE ES POSIBLE LA ECTURA INTENSA DE UNA

COMPOSICIÓN DE IMÁGENES BORDADAS. COMPOSICIÓN

MEDIDA, COMO LA POESIA. HABLAR DE POESIA, PARA ESTAS

MUJERES, ES HABLAR DE LAS “CANCIONES TEJIDAS" DE LOS

BORDADOS DE PALABRAS QUE CREAN ESE ESPACIO DONDE

SURGE LO SAGRADO EN EL MEDIO DE LAS COSAS DE TODOS

LOS DIAS (in:

https://www.revistadelauniversidad.mx/storage/7de7cd12-

3ec2-4407-9212-2945dd20f9c5.pdf)

O de todos os dias...

Vir pra FFP...

Dar aulas...

Participar alegremente de todas as atividades... inclusive as mais desinteressantes...

Ler textos...

Rabiscar produções dos alunos...

Comer pipoca do tio...

Comer coxinha na William...

Organizar a sucupira comigo e com marquinhos... 


\section{RevistAleph}

Aguentar uma greve firmes e fortes em 2016...

Organizar aulas públicas...

Produzir foros com estudantes...

Não deixar cair a peteca...

Resistir 2017..

Ocupar as ruas...

Ir a Assembleia da Asduerj...

Ir na manifestação em defesa da escola pública...

Compartilhar trocados...

Perguntar se necessita uma forza...

Falar com Ana Santiago.

Ligar para Mariza.

Ver com Odimar.

Mandar projeto de doutorado pra CAPES no meio da tormenta...

Ver Lula ser preso injustamente...

Gritar Lula livre em cada aniversário...

Levar o convidado ao aeroporto...

Ir ao cinema...

Ir a ultima exposição...

A FFP inteira com Jacque criando um tecido com outros...

A FFP como HUIPIL MEXICANO EM JACQUE: ESPACIO “DONDE SURGE LO SAGRADO EN EL MEDIO DE LAS COSAS DE TODOS LOS DIAS"

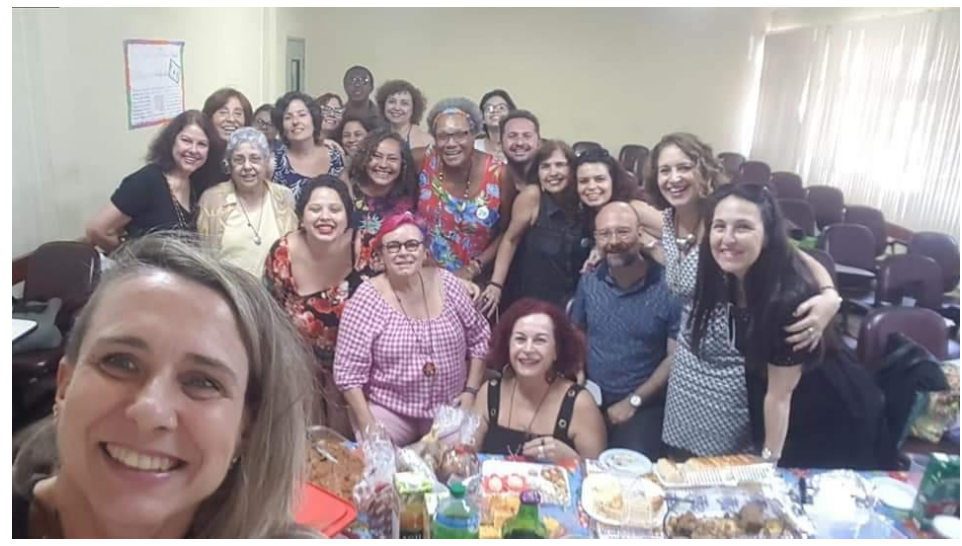

Tive a sorte de tecer com Jacque, parte desse huipil, desse texto... foi a FFP que me deu essa sorte. O huipil FFP que diz de todos nós... entre nós. Contra toda barbárie! Ô sorte!

Anelice Ribetto 